DOI https://doi.org/10.30525/978-9934-26-148-0-19

\title{
ИННОВАЦИОННОЕ ПОНИМАНИЕ КОНСТИТУЦИОННОЙ РЕДАКЦИИ СТАТЬИ О ПЯТИ СТУПЕНЯХ НЕДОПУСТИМОСТИ УХУДШЕНИЯ СОДЕРЖАНИЯ И/ЛИБО ОБЪЕМА ПРАВОВОГО СТАТУСА СОЦИОСУБЬЕКТОВ
}

\author{
Ланцедова Ю. А. \\ кандидат юридических наук, дочент, дочент кафедры криминального \\ права и прочесса юридического факультета \\ Национального авиационного университета \\ г. Киев, Украина \\ Тимченко Р. Ю. \\ соискатель высшего образования по специальности 081 Право \\ квалификационного уровня бакалавр факультета экономики и права \\ Международного классического университета имени Филиппа Орлика \\ г. Николаев, Украина
}

Разработанное и конструктивно развиваемое А.А. Кириченко, А.С. Тунтулой и Ю.А. Ланцедовой инновационное понимание пяти ступеней недопустимости ухудшения содержания и/либо объема правового статуса социосубьектов в виде соответствующей статьи перспективного Конституционного кодекса Украины, а равно любого иного государства мира [1, с. 60-82; 2, с. 80-83 и др.] более правильно представить в такой редакции :

XI. «Пять ступеней недопустимости ухудшения содержания и/либо объема правового статуса социосубьектов» :

«Недопустимость при принятии новых правовых актов либо внесения в них изменений или дополнений ухудшения содержания и/или объема правового статуса социосубьектов строится на признании в государстве и неуклонном соблюдении принципа верховенства права и имеет следующие степени защиты :

1. Первая ступень абсолютной недопустимости ухудшения содержания и/или объема тех проявлений правового статуса человека, относящихся к категории наивысших социальных ценностей, сущность которой заключается в том, что ни при каких, даже других исключительных, обстоятельствах не допускается при принятии правовых актов либо внесении в них изменений или дополнений, в т. ч. и в Конституционный кодекс Украины, дополнительное 
ухудшение содержания и/или объема тех проявлений правового статуса человека, которые признаны статей $\mathrm{X}$ Конституционного кодекса Украины наивысшими социальными ценностями с установлением исчерпывающего перечня исключительных обстоятельств, при наличии которых только и возможно такое ухудшение.

2. Вторая ступень абсолютной недопустимости ухудшения содержания и/или объема правового статуса социосубьектов в сравнении с соответствующими правоотношениями согласно правовому акту высшей юридической силы, сущность которой заключается в том, что ни при каких, даже исключительных, обстоятельствах не допускается при принятии правовых актов либо внесения в них изменений или дополнений дальнейшее ухудшение содержания и/или объема правового статуса человека по сравнению с соответствующими правоотношениями согласно правовому акту высшей юридической силы, то есть определенных их положений и/либо изменений и/или дополнений к ним :

- любого закона в сравнении с соответствующими положениями Конституционного кодекса Украины;

- любого подзаконного правового акта в сравнении с соответствующими положениями определенного закона и/или Конституционного кодекса Украины;

- подзаконного правового акта определенного субъекта властных полномочий в сравнении с соответствующими положениями подзаконного правового акта субъекта властных полномочий высшего уровня и/либо определенного закона и/или Конституционного кодекса Украины;

- любых текущих решений определенного субъекта властных полномочий в сравнении с соответствующими положениями подзаконного правового акта, принятого этим же субъектом властных полномочий, и/или подзаконного правового акта субъекта властных полномочий высшего уровня и/либо определенного закона и/или Конституционного кодекса Украины.

Дача согласия на обязательность для Украины определенных положений международного правового акта, противоречащих соответствующим положениям Конституционного кодекса Украины, осуществляется парламентом только одновременно с процедурой внесения таких изменений и/или дополнений в Конституционный кодекса Украины, которые уже в полной мере согласуются с положениями международного правового акта и вместе с этим не сужают по сравнению с предыдущей редакцией Конституционного 
кодекса Украины содержание и/или объем правового статуса соответствующих социосубьектов.

Невыполнение или ненадлежащее выполнение либо выполнение не в полном объеме указанных требований не распространяет на украинских социосубьектов действие ратифицированных парламентом соответствующих положений Международного правового акта.

3. Третья ступень относительной недопустимости при обычных обстоятельствах ухудшения содержания и/или объема правового статуса социосубьектов, сущность реализации которого заключается в том, что при отсутствии должным образом обоснованных исключительных обстоятельств не допускается при принятии правовых актов либо внесении в них изменений и/или дополнений ухудшение содержания и/или объема правового статуса физических и/или юридических лиц, государства и/или межгосударственных образований.

4. Четвертая ступень допустимости только исключительного и только временного ухудшения содержания и/или объема проявлений правового статуса социосубьектов, не относящихся к категории высших социальных ценностей, сущность которого заключается в том, что в случае обоснования парламентом наличия надлежащих исключительных обстоятельств допускается при принятии правовых актов либо внесении в них изменений или дополнений, в т. ч. в Конституционный кодекс Украины, ухудшение содержания и/или объема правового статуса физических и/или юридических лиц и/либо государства и/или межгосударственного образования с обязательным указанием на временность такого ухудшения и на его обязательное ослабление или вообще прекращение действия по мере соответствующего ослабления или прекращения действия указанных исключительных обстоятельств.

В случае своевременного невнесения изменений в правовой акт или в ранее внесенных в него изменений и/или дополнений, в т. ч. в Конституционный кодекс Украины, которые соответствующим образом ослабляют или прекращают действие такого ухудшения, все социосубьекты должны применять первичную редакцию правового регулирования соответствующих правоотношений, а Генеральная прокуратура Украины обязана безотлагательно по своей инициативе и/или иных социосубьектов обосновать фактическое отсутствие ослабления или прекращения действия соответствующих исключительных обстоятельств либо отменить соответствующее положение правового акта или изменений и/либо дополнений к нему, в т. ч. в Конституционный кодекс Украины, что только исключительно и только временно ухудшало при наличии определенных исключительных 
обстоятельств содержание и/или объем правового статуса тех или иных социосубьектов.

5. Пятая ступень абсолютной недопустимости обратного действия ухудшения содержания и/или объема правового статуса социосубьектов, сущность реализации которого заключается в том, что даже в случае обоснования наличия надлежащих исключительных обстоятельств и необходимости вследствие этого временного ухудшения содержания и/или объема правового статуса физических и/или юридических лиц и/либо государства и/или межгосударственного образования при принятии правовых актов либо внесении в них изменений и/или дополнений, в т. ч. в Конституционный кодекс Украины, запрещается, т. ч. и при наличии этих или любых иных исключительных обстоятельств, обратное действие таких ухудшающих содержание и/или объем правового статуса определенных социосубьектов правовых актов либо внесенных в них изменений и/или дополнений, в т. ч. и в Конституционный кодекс Украины, то есть распространение их действия на соответствующие уже начатые и продолжающиеся между этими социосубьектами правоотношения.

Такое незаконное распространение действия этих норм правовых актов не влечет за собой никаких юридических последствий и должны быть применены нормы правового акта либо изменений или дополнений к нему, в т. ч. в Конституционный кодекс Украины, существовавшие на момент начала соответствующих правоотношений между этими социосубъектами, а прокуратура по собственной инициативе или иных лиц должна возбудить в отношении лиц, виновных в незаконном распространении, судопроизводство с привлечением их к соответствующему виду, характеру и степени строгости юридической ответственности».

\section{Литература:}

1. Кириченко О. А., Ланцедова Ю. О., Тунтула О. С. Інновації юриспруденції та законності у сфері транспорту і транспортних технологій : монографія. Варшава : RS Global Sp.z O.O., 2021. 95 с. URL : https://monographs.rsglobal.pl/index.php/rsgl/catalog/book/37

2. Кириченко О. А., Тунтула О. С., Ткач Ю. Д. Інновації юриспруденції в забезпеченні журналістської галузі права та медіабезпеки : монографія. Варшава : RS Global Sp.z O.O., 2021. 98 с. URL: https://monographs.rsglobal.pl/index.php/rsgl/catalog/book/40 